\title{
PROGENY TESTING IN STREET TREES SUBJECTED TO ROADSIDE SOIL POLLUTION
}

\author{
by Oddmund Fostad and Per Anker Pedersen
}

\begin{abstract}
To investigate the relationship of the characteristics of offspring from selected individual urban trees to the fitness of the mother trees, seeds were collected in 1991 and 1992 from Acer platanoides (Norway maple), Aesculus hippocastanum (horsechestnut), and Betula pendula (silver birch) along streets in Oslo center, Norway. Half-sib families of $A$. platanoides, $A$. hippocastanum, and $B$. pendula, numbering 12,12 , and 6 , respectively, were grown in the roadside soil or in peat for 2 years (1992 and 1993) with seeds collected the previous year. Seedlings grown in the roadside soil were $64 \%$ shorter than those grown in peat. Stunting in roadside soil was greatest in $A$. platanoides and least in $B$. pendula. In $A$. platanoides, a significant correlation between height of the seedlings and vigor of the mother trees was found in 1993 but not in 1992. In A. hippocastanum, a correlation was found in both years. Within A. hippocastanum, best vigor and growth were found in seedlings originating from mother trees with excellent vigor, suggesting a potential for selective tree improvement. $B$. pendula produced the most homogeneous seedlings. Leaf drop occurred earlier in seedlings grown in roadside soil than in peat.
\end{abstract}

Keywords. Edaphic factors, growth suppression, halfsib families, inter- and intraspecific variation, phenology, roadside soil, selection, urban environment

Motor vehicles are major pollution sources. Exhaust gases, deicing salt, and wearing of pavement and vehicles may create adverse conditions for vegetation growth along highways. This complex pollution can result in high $\mathrm{pH}$ and increased levels of salts and heavy metals (Lagerwerf and Specht 1970; Harrison et al. 1981; Johnston and Harrison 1984; Thompson et al. 1986). Alkalization of the soils along roads is a common limitation of tree growth (Neely 1976; Harrel et al. 1984; Smiley at al. 1985; Smiley et al. 1986; Whitcomb 1986; Whitlow and Bassuk 1987; Ware 1990). More than $80 \%$ of urban tree problems are speculated to be related to adverse soil conditions (Patterson et al. 1980).

Roadside pollution has complicated the establishment and maintenance of vegetation (Gilbertson and Bradshaw 1985; Petersen and Eckstein 1988). Selection of species or individuals adapted to roadside environments is needed. Genetic variation of plants to pollution resistance is well known (Bradshaw 1959; Håbjørg 1975; Dochinger and Townsend 1979; Elkiey et al. 1979; Smith and Brennan 1984; Watmough and Dickinson 1996). Selection of pollution-tolerant roadside vegetation should be based on resistance to a broad range of stress factors. Gold (1975) emphasized that plant species must be selected for tolerance to urban conditions such as drought, poor aeration, compaction, mineral deficiencies, air pollution, mechanical impacts by humans, and contamination by salts, heavy metals, and pesticides.

Interspecific variation to urban stress is widely reported (Sanda 1979; Mitchell 1985; Pedersen 1990) but information on intraspecific variation is limited. In a recent study, Fostad and Pedersen (1997) described phenotypic variation in tolerance to roadside environment at both interspecific and intraspecific levels.

The objective of this study was to determine whether fitness of the offspring from selected individual urban trees was correlated with fitness of their mother trees. Half-sib families originating from the 3 most frequent street tree species in Oslo center, Norway (Acer platanoides [Norway maple], Aesculus hippocastanum [horsechestnut], and Betula pendula [silver birch]) were grown in contaminated roadside soils and in uncontaminated soils. The growth and development of the seedlings were then compared with the observed characteristics of the respective mother trees.

\section{Materials and Methods}

Based on a 3-year survey of urban trees in Oslo center (Fostad and Pedersen 1997), seeds were collected from selected individuals of Acer platanoides, Aesculus hippocastanum, and Betula pendula. The selected trees represented a range of phenotypes with respect to vigor or fitness in the urban environment. Seeds from 12 individuals of $A$. platanoides, 12 of $A$. 
hippocastanum, and 6 of $B$. pendula were collected in 1991 and 1992. Because some of the trees in the first year had few or no seeds in the second year, it was not possible to study the same families in both years.

Immediately after harvesting, the seeds of $A$. hippocastanum were sowed in $5 \mathrm{~cm}$ (2 in.) Jiffy® pots, and the seeds of $A$. platanoides and $B$. pendula were sowed in trays. Both the pots and trays were filled with Floralux® sphagnum peat. Seeds were covered with a thin layer of sand to reduce water loss, and pots and trays were stored at $-1^{\circ} \mathrm{C}\left(30.2^{\circ} \mathrm{F}\right)$. Seeds of $A$. platanoides and $A$. hippocastanum were stratified at $3^{\circ} \mathrm{C}\left(37.4^{\circ} \mathrm{F}\right)$ for 1 and 4 months, respectively. Both the pots and trays were brought into a heated, plastic-covered greenhouse on April 1. In the middle of April, the Acer and Betula seedlings were transplanted in $5 \mathrm{~cm}$ (2 in.) Jiffy® pots. After 4 weeks, one-third of the seedlings were transplanted in 3.5-L (1gal) plastic pots containing roadside soil, one-third were transplanted in 3.5-L plastic pots with sphagnum peat, and one-third were transplanted into beds filled with sphagnum peat. The plastic pots and beds filled with peat served as controls. The roadside soil was collected from the upper $5 \mathrm{~cm}$ (2 in.) of soil within a distance of $1.5 \mathrm{~m}(5 \mathrm{ft}$.) from the edge of a heavily traveled road $4 \mathrm{~km}(2.5 \mathrm{mi})$ south of Oslo. The roadside soil was mixed with $30 \%$ perlite by volume. Thirty seedlings of each half-sib family were used per treatment. The roadside soil was fertilized with $1.5 \mathrm{~kg} / \mathrm{m}^{3}\left(1 \mathrm{lb} / \mathrm{ft}^{3}\right)$ of water-soluble compound NPK (Fullgjødsel® 154-12) as a basal dressing. During the experiment, the seedlings were further fertilized with compound NPK and calcium nitrate $(15.5 \% \mathrm{~N})$ at the rate of $20 \mathrm{~g} / \mathrm{m}^{2}\left(0.7 \mathrm{oz} / \mathrm{ft}^{2}\right)$. Compound NPK was given 3 times, while calcium nitrate was given twice during the growing season. The seedlings were watered when needed. From the end of October to the end of April, the seedlings were stored in a storage room at $-2^{\circ} \mathrm{C}\left(28.4^{\circ} \mathrm{F}\right)$

Total increase in height $(\mathrm{cm})$, general appearance (rated on a scale of 0 to 9: $0=$ dead tree, 5 $=$ mediocre, and $9=$ excellent vigor), date of beginning leaf drop, and date of budbreak of terminal and lateral buds were recorded for all replications. Thereafter the gradual development of both the leaf drop and budbreak was assessed by giving scores on a scale of 0 to 9 , where 0 is no leaf drop or budbreak and 9 is complete leaf drop or budbreak. Seedling data were recorded once in the middle of August, twice weekly in September and October 1992, and in May and June 1993.

Twenty-eight leaf samples were collected from seedlings of each species and half-sib family to correlate the concentration of some macro- and micronutrients to growth parameters within the 3 species. All leaf samples were dried for 48 hours at $85^{\circ} \mathrm{C}$ to $90^{\circ} \mathrm{C}\left(185^{\circ} \mathrm{F}\right.$ to $\left.194^{\circ} \mathrm{F}\right)$ and milled before analysis. The samples were analyzed for $N$, $\mathrm{P}, \mathrm{K}, \mathrm{Ca}, \mathrm{Mg}, \mathrm{Cl}, \mathrm{Na}, \mathrm{Fe}, \mathrm{Cu}, \mathrm{Mn}, \mathrm{Zn}$, and $\mathrm{Al}$. Total $N$ in the dry plant material was analyzed by the Kjeldahl method. Concentrations of $\mathrm{P}, \mathrm{K}, \mathrm{Ca}$, $\mathrm{Mg}, \mathrm{Na}, \mathrm{Fe}, \mathrm{Cu}, \mathrm{Mn}, \mathrm{Zn}$, and $\mathrm{Al}$ were analyzed by Inductively Coupled Plasma (ICP) spectroscopy, and $\mathrm{Cl}$ concentrations were measured by Ion Chromatography (IC).

From the roadside soil and the peat, 8 samples were taken and analyzed for bulk density, EC (electrical conductivity), $\mathrm{pH}, \mathrm{P}-\mathrm{AL}, \mathrm{K}-\mathrm{AL}$, Mg-AL, Ca-AL, Na-AL, Mn, Pb, Cu, Zn, Fe, and $\mathrm{Cd}$. Measurements of EC were taken with a Philips PW 9529 Conductivity Meter. Concentrations of $\mathrm{P}, \mathrm{K}, \mathrm{Mg}, \mathrm{Ca}$, and $\mathrm{Na}$ were analyzed by the Ammonium Lactate $(A L)$ method (Egnér et al. 1960), and the heavy metals were analyzed by ICP.

The data were analyzed statistically using an analysis of variance procedure. The main effects of species and growth conditions were analyzed with the half-sib families nested within the species. Ryan-Einot-Gabriel-Welsh (REGWQ) multiple-range tests on all main effects were carried out at a significance level of $p=0.05$ using the GLM procedure of the SAS Institute (1982).

\section{Results}

Growth and development. On average, the seedlings gave a higher score of general appearance and gained more height in 1993 than in 1992, and seedlings cultivated in peat gained more height and were more vigorous than seedlings cultivated in the roadside soil (Table 1). In 1992 there were no significant differences be- 
Table 1. Mean height growth $(\mathrm{cm})$ and general appearance of seedlings from 3 species grown under 3 different conditions in 1992 and 1993.

\begin{tabular}{|c|c|c|c|c|}
\hline \multirow[b]{2}{*}{ Growth conditions } & \multicolumn{2}{|c|}{ Height growth } & \multicolumn{2}{|c|}{$\begin{array}{l}\text { General } \\
\text { appearance }\end{array}$} \\
\hline & 1992 & 1993 & 1992 & 1993 \\
\hline Roadside soil, pots & $25.6 b^{1}$ & $41.2 \mathrm{c}$ & $2.8^{2} \mathrm{~b}$ & $5.8 b$ \\
\hline Peat, pots & $86.8 \mathrm{a}$ & $91.9 b$ & $5.8 \mathrm{a}$ & $6.9 \mathrm{a}$ \\
\hline Peat, beds & $84.3 \mathrm{a}$ & $119.4 \mathrm{a}$ & $5.7 \mathrm{a}$ & $7.0 \mathrm{a}$ \\
\hline
\end{tabular}

tween the seedlings cultivated in pots and in beds with peat, but in 1993 the seedlings in beds grew significantly better than seedlings grown in pots. Seedlings cultivated in peat grew an average of $12 \%$ more in beds than in pots.

The seedlings grown in the roadside soil grew in height $64 \%$ less than seedlings grown in peat (Table 2). The mean general appearance score of the seedlings was also significantly reduced from 6.3 to 3.9 when grown in the roadside soil. In general $A$. platanoides and $B$. pendula grew better than $A$. hippocastanum, both in peat and in the roadside soil. However, B. pendula and $A$. platanoides responded quite differently to the 2 substrates. They showed very clear differences in height increase when grown in the roadside soil compared to peat. Growth differences between trees grown in roadside soil compared to peat was strongest in $A$. platanoides and weakest in $B$. pendula in both years (Table 2 ).

Inter- and intraspecific growth variation. Only small differences were observed in height increase between half-sib families of $A$. platanoides (Table 3). Seed sources with excellent vigor (score 7-9) produced offspring with significantly $(P=0.0001)$ better growth and general appearance than seed sources with lower scores in both soil types in 1993. In 1992, however, there was no significant $(P=0.86)$ correlation $\left(R^{2}=0.01\right)$ between the height of the seedlings and the vigor of the seed sources. Growth suppression of $A$. platanoides was $76 \%$ to $88 \%$ in 1992 and $37 \%$ to $86 \%$ in 1993 for seedlings cultivated in roadside soil compared to peat (Table 3).
Table 2. Mean height increase $(\mathrm{cm})$ and percentage growth differential in roadside soil compared to peat for Acer platanoides, Aesculus hippocastanum and Betula pendula, 1992 and 1993.

\begin{tabular}{lcccc}
\hline & & \multicolumn{3}{c}{ Height increase } \\
\cline { 2 - 5 } & Year & Peat & Roadside & Percent \\
\hline A. platanoides & 1992 & $129.6 \mathrm{a}^{2}$ & $21.6 \mathrm{~b}$ & $83.3 \mathrm{a}$ \\
& 1993 & $123.3 \mathrm{a}$ & $43.0 \mathrm{a}$ & $65.1 \mathrm{~b}$ \\
A. hippocastanum & 1992 & $26.2 \mathrm{~b}$ & $16.7 \mathrm{a}$ & $36.3 \mathrm{~b}$ \\
& 1993 & $31.6 \mathrm{a}$ & $17.4 \mathrm{a}$ & $44.9 \mathrm{a}$ \\
B. pendula & 1992 & $101.6 \mathrm{~b}$ & $60.9 \mathrm{~b}$ & $40.1 \mathrm{a}$ \\
& 1993 & $140.7 \mathrm{a}$ & $97.6 \mathrm{a}$ & $30.6 \mathrm{~b}$ \\
Mean & \multicolumn{5}{c}{38.9} & 31.6 & 64.4 \\
\hline
\end{tabular}

In $A$. hippocastanum, there was a significant $(P=0.0001)$ correlation $\left(\mathrm{R}^{2}=0.32-0.45\right)$ between the growth of seedlings and vigor of the seed source during both years. Seedlings originating from seed sources with mediocre (score 4-6) and excellent (7-9) vigor had better vigor than seedlings originating from seed sources with poor (1-3) vigor. Seedlings of highly vigorous mother trees of $A$. hippocastanum grew significantly $(P=0.0001)$ more than those from seeds collected from less vigorous mother trees.

A. hippocastanum seedlings grown in roadside soil increased in height $9 \%$ to $61 \%$ less than those grown in peat (Table 4). Two of the collected half-sib families ( $F$ and $G$ ) were more homogeneous and stable than the others. These half-sib families responded similarly in growth reduction in 1992 and 1993. They were both collected from trees of excellent vigor and no leaf damage. The slowest growing and least vigorous half-sib family (D) of this species came from a tree with low vigor and severe leaf damage.

Half-sib families of $B$. pendula were generally more homogeneous than the other 2 species, and no significant $(P=0.52)$ correlation $\left(\mathrm{R}^{2}=0.08\right)$ existed between growth and vigor of the different half-sib families and the vigor of the seed sources. Growth suppression was $22 \%$ to $39 \%$ for seedlings cultivated in roadside soil compared to peat (Table 5). 
Table 3. Height growth $(\mathrm{cm})$ and percentage growth differential in roadside soil compared to peat in different half-sib families of Acer platanoides, 1992 and 1993. The seed sources were of different vigor.

\begin{tabular}{|c|c|c|c|c|c|c|c|}
\hline \multirow[b]{3}{*}{ Half-sib family } & \multirow[b]{3}{*}{ Vigor of seed source } & & & \multicolumn{4}{|c|}{ Height growth } \\
\hline & & \multicolumn{2}{|c|}{ Peat } & \multicolumn{2}{|c|}{ Roadside soil } & \multicolumn{2}{|c|}{ Percentage $^{1}$} \\
\hline & & 1992 & 1993 & 1992 & 1993 & 1992 & 1993 \\
\hline A & $9^{2}$ & 117.6 & 121.1 & 23.0 & 49.3 & 80.4 & 59.3 \\
\hline B & 9 & 126.4 & 110.6 & 23.8 & 69.4 & 81.2 & 37.3 \\
\hline । & 9 & 92.6 & - & 10.9 & - & 88.2 & - \\
\hline$E$ & 7 & 108.3 & 108.0 & 22.0 & 41.3 & 79.7 & 61.8 \\
\hline $\mathrm{G}$ & 7 & 101.7 & 143.3 & 13.3 & 26.1 & 86.9 & 81.8 \\
\hline$L$ & 7 & - & 142.4 & - & 35.3 & - & 75.2 \\
\hline $\mathrm{F}$ & 6 & 100.8 & 126.7 & 13.5 & 42.8 & 86.6 & 66.2 \\
\hline $\mathrm{H}$ & 6 & 113.7 & 168.5 & 24.1 & 23.9 & 78.8 & 85.8 \\
\hline D & 5 & 115.2 & 132.3 & 22.2 & 47.3 & 80.7 & 64.2 \\
\hline $\mathrm{C}$ & 4 & 97.2 & 78.0 & 23.2 & 39.1 & 76.1 & 49.9 \\
\hline J & 4 & 119.3 & - & 25.1 & - & 79.0 & - \\
\hline$K$ & 3 & - & 108.3 & - & 19.0 & - & 82.5 \\
\hline
\end{tabular}

${ }^{1}$ Growth differential $(\%)$ in roadside soil compared to peat.

${ }^{2}$ Scale 0-9.

Table 4. Height growth $(\mathrm{cm})$ and percentage growth differential in roadside soil compared to peat in different progenies of Aesculus hippocastanum, 1992 and 1993. The seed sources were of different vigor.

\begin{tabular}{|c|c|c|c|c|c|c|c|}
\hline \multirow[b]{3}{*}{ Half-sib family } & \multirow[b]{3}{*}{ Vigor of seed source } & & & \multicolumn{4}{|c|}{ Height growth } \\
\hline & & \multicolumn{2}{|c|}{ Peat } & \multicolumn{2}{|c|}{ Roadside soil } & \multicolumn{2}{|c|}{ Percentage $^{1}$} \\
\hline & & 1992 & 1993 & 1992 & 1993 & 1992 & 1993 \\
\hline$G$ & 92 & 21.1 & 32.6 & 15.4 & 22.7 & 27.0 & 30.4 \\
\hline $\mathrm{K}$ & 9 & - & 18.5 & - & 11.9 & - & 35.7 \\
\hline A & 8 & 29.8 & 34.2 & 17.9 & 17.0 & 39.9 & 50.3 \\
\hline$F$ & 8 & 27.8 & 38.3 & 17.2 & 21.0 & 38.1 & 45.2 \\
\hline $\mathrm{H}$ & 8 & 27.0 & 53.5 & 21.9 & 21.1 & 18.9 & 60.6 \\
\hline $\mathrm{B}$ & 6 & 34.0 & 35.8 & 22.3 & 16.9 & 34.4 & 52.8 \\
\hline $\mathrm{C}$ & 6 & 23.1 & 26.5 & 14.2 & 13.0 & 38.5 & 50.9 \\
\hline$E$ & 5 & 22.9 & 18.5 & 14.1 & 11.9 & 38.4 & 35.7 \\
\hline$\vec{J}$ & 5 & 16.3 & - & 15.2 & - & 6.7 & - \\
\hline L & 4 & - & 25.8 & - & 14.9 & - & 42.2 \\
\hline I & 4 & 27.9 & - & 15.1 & - & 45.9 & - \\
\hline$D$ & 3 & 12.6 & 12.0 & 11.3 & 10.9 & 10.3 & 9.2 \\
\hline
\end{tabular}

1 Growth differential $(\%)$ in roadside soil compared to peat.

${ }^{2}$ Scale $0-9$.

Variation in leaf drop and budbreak. In all species, seedlings cultivated in roadside soil showed the earliest leaf drop. The best growing half-sib families of $A$. platanoides had an earlier leaf drop than the slowest growing families. No such relationship was found in the 2 other species.

The half-sib families of the $A$. platanoides from 1992 had earlier budbreak (4 days) the following spring when cultivated in peat than those culti- vated in the roadside soil. In the half-sib families from 1993, there were no differences between the treatments. Seedlings originating from trees of poor vigor, however, had an earlier budbreak (7 days) than seedlings of the mediocre and excellent vigorous seed sources.

Half-sib families of $A$. hippocastanum had an earlier budbreak ( 6 days) when cultivated in peat than those cultivated in the roadside soil. There were no differences in budbreak between the dif- 
Table 5. Height growth $(\mathrm{cm})$ and percentage growth differential in roadside soil compared to peat in different half-sib families of Betula pendula, 1992 and 1993. The seed sources were of different vigor.

\begin{tabular}{|c|c|c|c|c|c|c|c|}
\hline \multirow[b]{3}{*}{ Half-sib family } & \multirow[b]{3}{*}{ Vigor of seed source } & & & \multicolumn{4}{|c|}{ Height growth } \\
\hline & & \multicolumn{2}{|c|}{ Peat } & \multicolumn{2}{|c|}{ Roadside soil } & \multicolumn{2}{|c|}{ Percentage $^{1}$} \\
\hline & & 1992 & 1993 & 1992 & 1993 & 1992 & 1993 \\
\hline A & $8^{2}$ & 109.4 & 141.8 & 73.6 & 100.0 & 32.7 & 29.5 \\
\hline$E$ & 8 & 107.0 & - & 68.0 & - & 36.4 & - \\
\hline B & 7 & 103.6 & 149.0 & 63.4 & 91.7 & 38.8 & 38.5 \\
\hline C & 6 & 108.9 & 134.8 & 69.0 & 105.8 & 36.6 & 21.5 \\
\hline D & 6 & 65.2 & - & 40.6 & - & 37.7 & - \\
\hline $\mathrm{F}$ & 5 & - & 140.9 & & 88.3 & - & 37.3 \\
\hline
\end{tabular}

${ }^{\top}$ Growth differential (\%) in roadside soil compared to peat.

${ }^{2}$ Scale 0-9.

ferent half-sib families of the A. hippocastanum species.

Seedlings of $B$. pendula had earlier budbreak when grown in roadside soil (4 days), and there were no differences in budbreaks between different half-sib families.

Soil characteristics. The roadside soil was classified as a sandy loam with $5 \%$ to $10 \%$ clay and less than $3 \%$ organic matter. The soil reaction was alkaline with a high concentration of $\mathrm{Ca}$ (Table 6). The Na concentration was low, and the contents of other nutrients varied considerably. The concentration of $P$ was low, but that of $K$ and $\mathrm{Mg}$ was relatively high and very high, respectively. The levels of heavy metals were not especially high, except for $\mathrm{Pb}$ and $\mathrm{Cd}$.

Chemical composition of seedling leaves. Nutrient content in leaves varied among species and among plants cultivated in differerit soils. In general, leaves of plants grown in peat contained higher $\mathrm{N}$ concentrations than those grown in the roadside soil. Seedlings of $B$. pendula had lower concentrations of $\mathrm{N}, \mathrm{Cl}$, and $\mathrm{Ca}$, and a higher concentration of $\mathrm{Zn}$ than the 2 other species
(Table 7). The highest concentrations of $\mathrm{N}$ and $\mathrm{Cl}$ were found in the A. platanoides species. There were no differences in chemical concentrations between the half-sib families within the species.

\section{Discussion}

The purpose of this study was to focus on possible correlation between phenotypic appearance of selected seed sources of street trees and the growth and vigor of the offspring grown in the roadside soil. The results do reveal such correlations and thereby confirm that the selection of well-adapted street trees may provide a basis for seedling production of trees suited to the urban environment.

Poor seed quality in 1992 may have resulted in less height growth and less vigorous seedlings in 1992 than in 1993. A severe drought early in the summer and lower than normal precipitation from July through September 1991 was probably a main reason for this poor seed quality.

A significant correlation in A. platanoides between vigor of the seed sources and vigor and height of seedlings in 1993 was found. No such

Table 6. Electrical conductivity (EC), pH, chemical concentrations, and bulk density of the growth media-roadside soil (dust) and peat.

\begin{tabular}{|c|c|c|c|c|c|c|c|c|c|c|c|c|c|c|}
\hline & \multirow[b]{2}{*}{$\mathrm{EC}^{1}$} & \multicolumn{6}{|c|}{$\mathrm{mg} / 100 \mathrm{~mL}$} & \multicolumn{6}{|c|}{$\mathrm{mg} / \mathrm{L}$} & \multirow{2}{*}{$\frac{\mathrm{kg} / \mathrm{dm}^{3}}{\text { Density }}$} \\
\hline & & $\mathrm{pH}$ & P-AL & $\mathrm{K}-\mathrm{AL}$ & $\mathrm{Mg}-\mathrm{AL}$ & Ca-AL & Na-AL & $\mathrm{Mn}$ & $\mathrm{Pb}$ & $\mathrm{Cu}$ & $\mathrm{Zn}$ & $\mathrm{Fe}$ & $\mathrm{Cd}$ & \\
\hline Peat & 1.9 & 5.4 & 19 & 29 & 21 & 329 & 3 & 18.0 & 6.0 & 6.0 & 12.0 & - & 0.11 & 0.25 \\
\hline $\begin{array}{l}\text { Roadside } \\
\text { soil }\end{array}$ & 1.1 & 7.9 & 2 & 8 & 17 & 1130 & 6 & 2.3 & 224.0 & 9.8 & 70.2 & 46.5 & 0.56 & 1.19 \\
\hline
\end{tabular}


Table 7. Mean chemical leaf concentrations for Acer platanoides, Aesculus hippocastanum, and Betula pendula.

\begin{tabular}{|c|c|c|c|c|c|c|c|c|c|c|c|c|}
\hline & \multicolumn{7}{|c|}{$\mathrm{g} / 100 \mathrm{~g}$ dry weight } & \multicolumn{5}{|c|}{$\mathrm{mg} / \mathrm{kg}$ dry weight } \\
\hline & $N$ & $P$ & $\mathrm{~K}$ & $\mathrm{Ca}$ & $\mathrm{Mg}$ & $\mathrm{Na}$ & $\mathrm{Cl}$ & $\mathrm{Fe}$ & $\mathrm{Cu}$ & $\mathrm{Mn}$ & $\mathrm{Zn}$ & $\mathrm{Al}$ \\
\hline A. platanoides & $2.08 \mathrm{a}^{1}$ & $0.45 \mathrm{a}$ & $2.03 a$ & $1.86 \mathrm{~b}$ & $0.25 \mathrm{~b}$ & $0.10 \mathrm{a}$ & $0.71 \mathrm{a}$ & $108.9 \mathrm{a}$ & $7.07 \mathrm{a}$ & $892.3 \mathrm{a}$ & $55.5 \mathrm{~b}$ & $110.7 \mathrm{a}$ \\
\hline A. hippocastanum & $1.92 \mathrm{a}$ & $0.23 \mathrm{a}$ & $1.60 \mathrm{ab}$ & $2.29 \mathrm{a}$ & $0.27 a b$ & $0.08 \mathrm{ab}$ & $0.54 b$ & $106.1 \mathrm{a}$ & $7.30 \mathrm{a}$ & $397.3 \mathrm{a}$ & $28.2 \mathrm{~b}$ & 74.6 a \\
\hline
\end{tabular}

effect was observed in 1992. These results show that, within this species, prediction of fitness from seed source characteristics is difficult.

Within A. hippocastanum, however, there was a significant correlation between vigor and leaf damage of the seed source, and between height and vigor of seedlings, in both years. The variation in height growth and vigor between the different half-sib families originating from seed sources reflects the variation in vigor of the seed sources. This species shows a great potential for improvement of street-tree quality by careful selection of phenotypically well-adapted seed sources. However, it is possible that some of the measured effects may be due to low seed quality of the least vigorous seed sources.

Betula pendula produced the most homogeneous and tolerant seedlings of this study. This is in agreement with the survey of street trees in Oslo center (Fostad and Pedersen 1997). Therefore, the potential for improving the quality of this species by selection seems smaller than that of A. hippocastanum.

Spring budbreak was more variable than fall leaf drop time for all species. In all species, leaf drop began earlier when the seedlings were grown in roadside soil than in peat. The advanced leaf drop in these seedlings was possibly due to stress caused by the impaired edaphic conditions. Similar observations were made by others (Håbjørg 1972; Grimstad 1977; Pedersen 1990). Seedlings originating from trees with poor vigor showed an earlier budbreak than seedlings originating from seed sources of mediocre and excellent vigor. Both $A$. platanoides and $A$. hippocastanum showed an earlier budbreak for peat-grown seedlings, whereas the reverse was true for $B$. pendula seedlings.
The roadside soil used for screening plants in this study showed a characteristic concentration of elements similar to that reported by others (Harrison et al. 1981; Johnston and Harrison 1984; Thompson et al. 1986; Pedersen 1990). Soil pH and concentrations of $\mathrm{Ca}$ and $\mathrm{Mg}$ were higher, but concentrations of $\mathrm{Na}$ were surprisingly low compared to the observations by other investigators. The heavy metal contents were in the normal range except for $\mathrm{Pb}$ and $\mathrm{Cd}$, which were about 19 and 7 times, respectively, above values reported as normal by Schachtschabel et al. (1989).

Although deicing salt has attributed to decline of street trees in Oslo center (Fostad and Pedersen 1997), it was not the main cause for reduction in growth and vigor in this study. The low content of $\mathrm{Na}$ in the roadside soil shows that $\mathrm{Na}$, along with $\mathrm{Cl}$, was leached out of the upper layer of the roadside soil before the soil was collected in September. The poor plant growth in the roadside soil is more likely a result of a combination of inadequate nutrition, high $\mathrm{pH}$, and high levels of $\mathrm{Pb}$ and $\mathrm{Cd}$.

Leaf analyses revealed considerable variation between different species grown under the same soil conditions, as was also reported by Vigerust and Selmer-Olsen (1985). Variation in the chemical composition between cultivars of the same species has been detected by Carlton-Smith and Davis (1983), but no such differences between different half-sib families within the same species were detected in this study. Leaf analysis did not show any relationship between growth and vigor and nutrient content.

Acknowledgements. This project was partly financed by the Norwegian Public Roads Administration Oslo. The authors gratefully acknowledge 
Ann-Helen Kalfjøs and Ellen Zakariassen for technical assistance and Atle Håbjørg for initiating this study.

\section{Literature Cited}

Bradshaw, A.D. 1959. Pollution differentiation in Agrostis tenuis Sibth. III. Populations in varied environments. New Phyt. 59:92-103.

Carlton-Smith, C.H., and R.D. Davis. 1983. Comparative uptake of heavy metals by forage crops grown on sludge-treated soil. Heavy metals in the environment. Int. Conf. Heidelberg, Proceedings 1:393-396.

Dochinger, L.S., and A.M. Townsend. 1979. Effects of roadside deicer salts and ozone on red maple progenies. Environ. Pollut. 19:229-237.

Egnér, H., H. Riehm, and W.R. Domingo. 1960. Untersuchungen über die chemische BodenAnalyse als Grundlage für die Beurteilung des Nährstoffzustandes der Boden. Kungl. Lantbrukshögskolans Annaler 26:199-215.

Elkiey, T., D.P. Ormrod, and R.L. Pelletier. 1979. Stomatal and leaf surface features as related to the ozone sensitivity of petunia cultivars. J. Amer. Soc. Hort. Sci. 104:510-514.

Fostad, O., and P.A. Pedersen. 1997. Vitality, variation, and causes of decline of trees in Oslo center (Norway). J. Arboric. 23:155-165.

Gilbertson, P., and A.D. Bradshaw. 1985. Tree survival in cities: the extent and nature of the problem. Arboric. J. 9:131-142.

Gold, S.M. 1975. Human responses in cities. Amer. Assoc. Bot. Gard. Arbor. Bull. 9:40-43.

Grimstad, S.O. 1977. Plant growth in industrial environment (in Norwegian). Master Thesis. Agricultural University of Norway. Ås. Norway. $69 \mathrm{pp}$.

Harrel, M.O., P.A. Pierce, D.P. Mooter, and B.L. Webster. 1984. A comparison of treatment for chlorosis of pin oak and silver maple. J. Arboric. 10:246-249.

Håbjørg, A. 1972. Air pollution and vegetation II. Effects of fertilization on growth and development of twenty woody plants grown in industrial areas (in Norwegian). Scientific reports of the Agricultural University of Norway: 52(2).

Håbjørg, A. 1975. Air pollution and vegetation III. Effects of air pollution on growth of Alnus incana (L.) Moench., Sorbus aucuparia L. and Uimus glabra Huds. cultivated in containers at three localities in Southern Norway (in Norwegian). Scientific reports of the Agricultural University of Norway: 54 (25).
Harrison, R.M., D.P.H. Laxen, and S.J. Wilson. 1981. Chemical associations of lead, cadmium, copper and zinc in street dusts and roadside soils. Environ. Sci. \& Technol. 15:1378-1383.

Johnston, W.R., and R.M. Harrison. 1984. Deposition of metallic and organic pollutants alongside the M6 motorway. Sci. Tot. Environ. 3:119-127.

Lagerwerf, J.V., and A.W. Specht. 1970. Contamination of roadside vegetation with cadmium, nickel, lead and zinc. Environ. Sci. Technol. 4:583-586.

Mitchell, A. 1985. Trees for towns and cities. Arboric. J. 9:271-278.

Neely, D. 1976. Iron deficiency chlorosis of shade trees. J. Arboric. 2: 128-130.

Patterson, J.C., J.J. Murray, and J.R. Short. 1980. The impact of urban soils on vegetation. Metria Proc. 3:33-56.

Pedersen, P.A. 1990. Roadside pollution and vegetation (in Norwegian). Dr. Scient. Thesis. Agricultural University of Norway. Ås. Norway. 106 pp.

Petersen, A., and D. Eckstein. 1988. Roadside trees in Hamburg-their present situation of environmental stress and their future chance for recovery. Arboric. J. 12:109-117.

Sanda, J.E. 1979. Initiative against salt injury on vegetation (in Norwegian). Forskn. Fors. Landbr. 30:333-353.

SAS Institute. 1982. SAS User's Guide: Statistics. Cary, North Carolina. 584 pp.

Schachtschabel, P., H.P. Blume, G. Brümmer, K-H. Hartge, and U. Schwertmann. 1989. Lehrbuch der Bodenkunde. Ferdinand Enke Verlag, Stuttgart. $491 \mathrm{pp}$.

Smiley, E.T., J.B. Hart, and J.J. Kielbaso. 1985. Foliar nutrient diagnosis of urban sugar and red maples in the Great Lakes Region. J. Environ. Hort. 3:104107.

Smiley, E.T., J.J. Kielbaso, and P.V. Nguyen. 1986. Soil factors associated with manganese deficiency of urban sugar and red maples. J. Arboric. 12:169173.

Smith, G.C., and E.G. Brennan. 1984. Response of honeylocust cultivars to air pollution stress in an urban environment. J. Arboric. 10:289-293

Thompson, J.R., A.J. Rütter, and P.S. Ridout. 1986. The salinity of motorway soils II. Distance from the carriage way and other sources of local variation on salinity. J. Appl. Ecol. 23:269-280.

Vigerust, E., and A.R. Selmer-Olsen. 1985. Heavy Metal Uptake in Plants Grown on Sludge-Treated 
Soil. Series B 2/85. Agricultural University of Norway. $58 \mathrm{pp}$.

Ware, G. 1990. Constraints to tree growth imposed by urban soil alkalinity. J. Arboric. 16:35-38.

Watmough, S.A., and N.M. Dickinson. 1996. Variability of metal resistance in Acer pseudoplatanus $L$. (sycamore) callus tissue of different origins. Environ. Exp. Bot. 36:293-302.

Whitcomb, C.E. 1986. Solving the iron chlorosis problem. J. Arboric. 12:44-48.

Whitlow, T.H., and N.L. Bassuk. 1987. Trees in difficult sites. J. Arboric. 13:10-17

\section{Department of Horticulture and Crop Sciences Agricultural University of Norway Box 5022, N-1432 Ås, Norway}

Résumé. Des semences de Acer platanoides, Aesculus hippocastanum et Betula pendula provenant d'arbres de rues d'Oslo en Norvège ont été plantées dans un milieu de culture fait de terre semblable à celle le long des rues ainsi que dans de la tourbe, et ce durant deux ans. Les semis plantés dans de la " terre de rue " étaient de $65 \%$ inférieurs en hauteur à ceux plantés dans la tourbe. Les retards de croissance étaient plus importants chez $A$. platanoides et les moindres chez $B$. pendula. Une corrélation significative entre la vigueur des arbres-mère et la hauteur des semis a été découverte dans la première saison de croissance, mais pas dans la seconde, pour $A$. platanoides; dans les deux saisons de croissances pour $A$. hippocastanum, mais dans aucune des deux pour $B$. pendula. Tous les arbres plantés dans de la " terre de rue" perdaient leurs feuilles plus tôt que ceux dans de la tourbe.

Zusammenfassung. Die Samen von von verschiedenen Straßenbäumen in Oslo, Acer platanoides, Aesculus hippocastanum und Betula pendula, wurden für zwei Wachstumpsperioden in Boden aus dem Straßenraum und in Torf gepflanzt. Die Sämlinge in dem Straßenboden waren $65 \%$ kleiner als die Bäume im Torf. Das verminderte Wachstum in Straßenboden war am stärksten bei $A$. platanoides und am wenigsten bei $B$. pendula. Es gab eine signifikante Korrelation zwischen der Lebenskraft der Mutterbäume und den Sämlingen in der ersten, aber nicht in der zweiten Wachstumsperiode bei $A$. platanoides, in beiden Perioden bei $A$. hippocastanum, aber in keiner Periode bei der B. pendula. Alle Bäume in Straßenboden ließen eher ihr Laub fallen als die in Torf gezogenen Bäume. 